IZA DP No. 5516

Immigrants and Welfare Receipt in Ireland

Alan Barrett

Corona Joyce

Bertrand Maître

February 2011 


\title{
Immigrants and Welfare Receipt in Ireland
}

\author{
Alan Barrett \\ Economic and Social Research Institute, Dublin \\ and IZA \\ Corona Joyce \\ Economic and Social Research Institute, Dublin \\ Bertrand Maître \\ Economic and Social Research Institute, Dublin
}

\author{
Discussion Paper No. 5516 \\ February 2011
}

\author{
IZA \\ P.O. Box 7240 \\ 53072 Bonn \\ Germany \\ Phone: +49-228-3894-0 \\ Fax: +49-228-3894-180 \\ E-mail: iza@iza.org
}

\begin{abstract}
Any opinions expressed here are those of the author(s) and not those of IZA. Research published in this series may include views on policy, but the institute itself takes no institutional policy positions.

The Institute for the Study of Labor (IZA) in Bonn is a local and virtual international research center and a place of communication between science, politics and business. IZA is an independent nonprofit organization supported by Deutsche Post Foundation. The center is associated with the University of Bonn and offers a stimulating research environment through its international network, workshops and conferences, data service, project support, research visits and doctoral program. IZA engages in (i) original and internationally competitive research in all fields of labor economics, (ii) development of policy concepts, and (iii) dissemination of research results and concepts to the interested public.
\end{abstract}

IZA Discussion Papers often represent preliminary work and are circulated to encourage discussion. Citation of such a paper should account for its provisional character. A revised version may be available directly from the author. 
IZA Discussion Paper No. 5516

February 2011

\section{ABSTRACT}

\section{Immigrants and Welfare Receipt in Ireland ${ }^{*}$}

Since 2004, Ireland has included in its system of social welfare payments criteria for receipt which limit the extent to which immigrants can receive welfare payments. In this paper, we compare the rates of receipt of welfare for immigrants and natives to see if the outcome is consistent with the operation of this policy. Using data from 2008, we generally find lower rates of welfare receipt among immigrants. While the numbers of immigrants claiming unemployment-related payments surged at the outset of the recession, there appears to have been a quicker stabilisation in the number of immigrants claiming such benefits relative to natives, based on official data from 2007 to 2010. This would be consistent with the on-going implementation of the type of criteria introduced in 2004.

JEL Classification: $\quad$ I38, J61

Keywords: Ireland, immigrants, welfare

Corresponding author:

Alan Barrett

Economic and Social Research Institute

Whitaker Square

Sir John Rogerson's Quay

Dublin 2

Ireland

E-mail: Alan.Barrett@esri.ie

* The authors are grateful for comments received at a seminar on this topic held at the ESRI in May 2010. All errors are our own. 


\section{Section 1: Introduction}

In many countries, the interaction between immigration policies and welfare policies are controversial. As discussed in Barrett and McCarthy (2008), one element of the debate is the extent to which immigrants make demands on welfare systems (Riphahn, 2004; Hansen and Lofstrom, 2009) and the consequences for the public finances in host countries (Dustmann et al, 2010). A second element in the debate focuses on the extent to which generous welfare regimes attract immigrants with a propensity to draw on the services of the welfare state (Borjas, 1999).

Our objective in this paper is to examine the issue of welfare use by immigrants in Ireland, focussing on whether immigrants are more or less likely to receive payments relative to natives. Ireland is a particularly interesting case study for this question. Since mid-2004, when immigration into Ireland accelerated on account of the expansion of the EU, Ireland has sought to limit the possibility for immigrants to access welfare by imposing conditions for receipt. As discussed below, initially the condition was based on residency, with two years of continuous residency being required before welfare could be accessed. Over time, this condition has evolved into a set of five criteria, one of which is a "centre of interest" test.

We look at the question of immigrant welfare receipt relative to natives by comparing the proportions of immigrants and natives in receipt of various payments, initially without adjusting for socio-economic characteristics. We then go on to use regression analysis to explore whether there is an independent effect of immigrant status on the likelihood of receiving welfare, controlling for factors such as education and gender. As shown in earlier research on immigrants in Ireland, the experiences of immigrants tend to differ across national groups so we explore the issues in question by looking at broad national groups separately. We use data from the Irish component of the EU Survey on Income and Living Conditions (EU-SILC) for 2008.

The question of immigrant welfare use in Ireland has been examined previously by Barrett and McCarthy (2007 and 2008). However, in those papers data from 2004 and 2005 were used and this represented a major limitation. As immigration into Ireland accelerated dramatically after the accession into the EU of ten new members in May 2004, data from 2004 and 2005 could not capture satisfactorily the experience of the new wave of immigrants. As a result, the analysis in this paper is the first to capture the post-2004 situation as data from 2008 is used. Also in this paper, we base some of the analysis on a merging of three waves of the EU-SILC (2006 to 2008). As a final element in this paper, we look at how the receipt of unemployment-related payments has evolved over the recession in Ireland for immigrants and natives. Given that Ireland has recently experienced one of the deepest recessions in the developed world since the 1930s, it is important to look at the recent experience.

The remainder of the paper is structured as follows. In Section 2, by way of providing context, we look at previous work within the economics literature on immigrants and welfare in Ireland. We also look at the most important legislative issue of relevance, namely, the habitual residence condition for receipt of welfare by immigrants. In Section 3, we describe the data on which the analysis is based. We then go on to 
present the results of the analysis. In Section 4, we look at the trend in receipt of unemployment payments by natives and non-natives over the course of the recession. In Section 5, we offer some conclusions.

Section 2: Context - literature and legislation

\section{Literature}

Barrett and McCarthy (2007) used data from EU-SILC 2004 to look at this question of the relative rates of receipt of welfare across immigrants and natives. As a first step, they report the proportions of immigrants and natives who report having received a payment under at least one of four payment-categories in the previous twelve months. The four categories are unemployment benefits and assistance, and disability payments and assistance. The sample is restricted to people of working age only and so the issue of old age pensions does not arise. This simple piece of analysis reveals that 15 percent of natives received some form of payment compared to only 7 percent of immigrants.

As immigrants in Ireland have been shown consistently to have higher rates of education relative to natives (Barrett, Bergin and Duffy, 2006), it could have been the case that the lower rates of welfare receipt by immigrants was the result of different educational attainment as opposed to immigrants status per se. For this reason, it was necessary to use regression analysis to see if an "immigrant effect" still existed once the analysis included controls for relevant socio-economic characteristics. By running probit models, Barrett and McCarthy showed that immigrants were still less likely to have received payments, even when controlling for factors such as educational attainment, with the marginal effect estimated at 5 percent.

Barrett and McCarthy developed this analysis along three lines. First, they broke the single immigrant group into two sub-groups - those from English-speaking and nonEnglish-speaking countries. However, no statistically significant difference was found between these sub-groups. Second, instead of looking at all people of working age, they restricted their sample to people who were unemployed. When they did this, they found that immigrants were 25 percent less likely to have received payments. As there was no statistically significant difference between immigrants and natives in their likelihood of being unemployed, Barrett and McCarthy took this estimate of 25 percent as indicating differences in eligibility or differences in willingness to apply.

The third and final extension by Barrett and McCarthy was to consider the amount received as opposed to the more limited question of whether any payment was received. The results suggested lower payments for immigrants relative to natives.

The same two authors returned to this issue in their later paper, Barrett and McCarthy (2008). This time data from EU-SILC 2005 was used. Although only a year had elapsed between the collection of this and the earlier data, some interesting differences emerged in the results. In particular, the 2005 data showed stronger differences between immigrants from English-speaking and non-English-speaking countries. When a probit regression was run for the whole sample, there was no difference between the likelihood of receipt of welfare for natives and immigrants from English-speaking countries. However, for immigrants from non-Englishspeaking countries the estimated marginal effect was -8 percent (t-statistic is 2.6). 
This difference between the two immigrants groups became larger when the analysis is restricted to the unemployed only. There was still no statistically significant difference between natives and immigrants from English-speaking countries in terms of likelihood of receiving payments. However, unemployed immigrants from nonEnglish-speaking countries were estimated as being 62 percent less likely to receive payments relative to unemployed natives.

This last finding again pointed to a possibility that immigrants from non-Englishspeaking countries had lower rates of eligibility relative to natives. One obvious factor that could explain this was the presence in Irish legislation of a "habitual residency condition". Given the potential importance of this when interpreting the results in the two Barrett and McCarthy papers and the results below, it is useful to set out the details of this condition for welfare receipt.

\section{Legislation}

Social welfare payments in Ireland are made through contributory or insurance-based payments (without a means test) and through non-contributory payments (which are dependent upon a means test). Basic social insurance payments are paid to those who have successfully made the required number of insurance contributions (known in Ireland as Pay-Related Social Insurance or PRSI). Examples of payments include Jobseeker Benefit, Maternity Benefit, Carer's Benefit, Disability Benefit and Contributory Old-Age Pension.

Social assistance payments, known as non-contributory payments, are means-tested with individuals required to prove their inability to support themselves through: any income belonging to them, a spouse or partner; any property in excess of their primary residence; and assets which could theoretically provide an income. Noncontributory payments include Jobseeker's Allowance, One-Parent Family Payment, Pre-Retirement Allowance, Non-Contributory Old Age Pension and Carer's Allowance Supplementary Welfare Allowance.

In the run up to the accession of ten new members of the EU in May 2004, concerns were expressed about the potential for the social welfare system to be put under pressure if there was a large inflow of welfare-prone immigrants from the new member states. In order to guard against this possibility, the government introduced a habitual residence condition for the receipt of social payments. The introduction of a HRC from 1 May 2004 saw a marked change regarding eligibility for many welfare payments for all nationalities (including Irish nationals) whereby access was conditional on a period of residence within Ireland or the UK. Initially, the Social Welfare (Miscellaneous Provisions) Act, 2004 (Section 17) (Commencement) Order, 2004 outlined a basic requirement for a person to be deemed 'habitually resident' from residence in Ireland or the UK for a continuous period of two years before making an application for certain social welfare payments.

Certain amendments to the habitual residence condition were introduced in subsequent years but the essential feature of Irish policy remained, namely, the existence of conditions which provided for the possibility of denying welfare payments to immigrants whose current and future attachment to Ireland could be shown to be weak. As of now, decisions on payments to immigrants are based on the following five criteria: 
- Length and continuity of residence in Ireland or in any other particular country;

- Length and purpose of any absence from Ireland;

- Nature and pattern of employment;

- Person's main centre of interest;

- Future intentions of the person as they appear from all the circumstances.

Should an immigrant fail to satisfy these criteria, based on an assessment by an official from the Department of Social Protection, they can be refused payments. In this way there is a degree of discretion built into the system of determination of habitual residence which provides scope for differential treatment of immigrants and natives. It is the existence of this mechanism which must be kept in mind as we look at the relative rates of receipt of payments across immigrants and natives in the sections below.

\section{Section 3: Data and Results}

The data on which the analysis below is based come from the EU Survey on Income and Living Conditions (EU-SILC) for 2008. A full description of the sampling methodology can be found in Central Statistics Office (2009) but here we will set out the broad features of the survey. The EU-SILC is a voluntary survey of private households and is carried out under EU legislation. To date, it has been used mainly to provide information on the rates of poverty and deprivation in Ireland (CSO, 2009). The survey seeks to provide a nationally representative sample of households. It does so by first creating a sample of 2600 small areas and then selecting a random sample of households within each block. About 130 households were surveyed each week during the twelve months of 2008, resulting in a sample of 5,247 households and 12,551 individuals.

For each individual, the survey contains information on variables such as age, education, labour force status and earnings. It also contains information on whether or not each individual was in receipt of a wide range of social welfare payments in 2007, the year preceding the survey. Crucially for our purposes, the place of birth and citizenship of each respondent is provided and we use these to identify the immigrants in the sample. If an individual reports themselves as having been born in Ireland and as being an Irish citizen, we code them as being a native. If an individual reports that they were born outside of Ireland and that they are not Irish citizens, we code them as being immigrants.

Our focus is on people of working age so we exclude people under the age of 18 and over the age of 65 . When individuals with missing values on any of the variables of interest are excluded, our final sample amounts to 6,441 individuals. Of these, 264 are immigrants which is 4.3 percent of the sample. We know from Census 2006 that over 10 percent of the population then was made up of non-nationals so there is a clear under-representation of immigrants in our sample. Barrett and McCarthy (2007) found a similar under-representation but argued that the characteristics of the immigrants in the EU-SILC sample mirrored the characteristics of immigrants in the, much larger, Quarterly National Household Survey (QNHS). 
In Table 1, we show the proportions of immigrants and natives who received various types of payments in 2007 (it should be remembered that although we are using data which was collected in 2008, the information of payments received refers to 2007). The first panel of the table looks at the following payments combined: unemployment benefits and assistance, disability benefits and assistance, and family benefits. Our data show that 66.1 percent of natives received a payment under at least one of these headings in 2007. For immigrants, the corresponding figure was 63.3 percent. Although the proportion for immigrants is lower, the chi-square test for the statistical significance of the different indicates that there is no statistical difference.

Following Barrett and McCarthy (2007 and 2008), we go on to break up the immigrant group into two sub-groups, those from English-speaking countries (of whom there are 82) and from non-English speaking countries (of whom there are 182). The proportion of immigrants from English-speaking countries who received a welfare payment in 2007 was 69.5 percent; the corresponding figure for immigrants from non-English-speaking countries was 60.4 percent. Neither of these proportions is statistically different from the native proportion. We add another perspective by considering as sub-groups immigrants from the pre-2004 EU (numbering 116 in the sample) and those from the post-accession New Member States (numbering 84). Although the New Member State (NMS) sub-group show the lowest proportion in receipt of any payment in 2007, there is again no statistical difference between this group and the native population.

In the second panel of Table 1, we look at unemployment and disability payments combined and at this point statistically significant differences begin to emerge between some immigrant groups and the native population. For all immigrants, combined, we see that 16.7 percent received some form of payment in 2007 - the corresponding figure for natives was higher, and statistically so, at 27.5 percent. There is no statistically significant difference between natives and immigrants from either English-speaking countries or the pre-accession EU. However, immigrants from nonEnglish speaking countries and from the NMS are less likely to have received payments and the difference is statistically significant. In the third panel of Table 1 we look at the receipt of family-related benefits but there are no statistically significant differences across the groups.

The overall picture that emerges from Table 1 is that where statistically significant differences exist between immigrants and natives in terms of their likelihoods of having received welfare payments, immigrants are less likely to have received payments. Although this observation is interesting in itself, it gives rise to the usual question of whether this is related to the characteristics of immigrants that may be associated with patterns of welfare receipt or whether there is an independent immigrant effect. For example, more highly educated people are less likely to receive social welfare payments. For this reason, if immigrants are more highly educated relative to natives this could explain their lower rate of welfare receipt. We need to control for relevant socio-economic characteristics in assessing the relative likelihoods for immigrants and natives of receiving welfare payments. We do this through regression analysis.

Before looking at the regression results, it is useful to look at the characteristics of the immigrant and natives, and within the immigrant sub-groups. Table 2 provides 
information on average ages, average numbers of years worked and average number of children. Table 3 shows relative levels of educational attainment. It is clear from Table 2 that the immigrants from the non-English speaking countries are younger than the natives and have fewer years of work experience. They also have fewer children. In terms of educational attainment, we see that immigrants are relative highly educated when compared to natives, a finding that has emerged in papers such as Barrett et al (2006) when using the Quarterly National Household Survey (QNHS). We also see that among the immigrant sub-groups, educational attainment is lowest among immigrants from the NMS. This was previously seen in Barrett and Duffy (2008) who also used the QNHS.

In order to see how these characteristics might combine to alter the picture given above of the relative likelihoods of welfare receipt by immigrants and natives, we present the results from the first of our regressions in Table 4. We should point out the regressions are probit regressions, due to the binary nature of the dependent variable. We present the marginal effects in the tables as opposed to coefficients because the non-linear nature of the estimates makes the interpretation of the coefficients difficult.

In Table 4, the dependent variable is whether any of the following payments were received in 2007: unemployment benefits and assistance, disability benefits and assistance and family benefits. As such, Table 4 is the multivariate equivalent of the first panel in Table 1. The first column of marginal effects shows that there is no statistically significant difference between natives and all immigrants combined. This was also the case in the raw data and so controlling for factors such as education and work experience is not altering the basic picture. There are no statistically significant differences between immigrants and natives when we break the immigrants into the sub-groups based on whether they come from countries that speak English. However, we do find a statistically significant result when we look at the immigrants from the NMS - they are almost 19 percent less likely to receive benefits relative to natives.

In Table 5, the dependent variable is limited to the receipt of unemployment and disability payments only, mirroring the second panel of Table 1 . As was the case when comparing the first panel in Table 1 and Table 4, the results are similar. The probit regression shows that immigrants are 7 percentage points less likely to have received an unemployment or disability payment in 2007. However, for immigrants from English speaking countries and from the pre-accession EU, the difference is not significant. For immigrants from non-English speaking countries and from the NMS, they are less likely to have received such payments relative to natives and the differences are statistically significant.

In Table 6, we show the regression results in respect of family benefits. As might have been expected based on the third panel of Table 1, no statistically significant marginal effects show up across any of the immigrant groups.

A finding that has emerged in the international literature in this area is that refugees often experience higher rates of welfare receipt relative to both natives and other immigrants. One such example is Hansen and Lofstrom (2009) who consider the Swedish situation. In our data it is not possible to identify refugees as such. However, we thought it was important to try to get some sense of this issue for Ireland. One 
route which we explored was to look at the countries from which persons with refugee status were likely to come and to use this as a proxy of such a status.

When we tried to put this approach into operation, we found that we had only 22 individuals in the 2008 sample who were from countries that showed up as being among the ten largest sources of applicants for asylum. For this reason we tried to pool data from three waves of the EU-SILC, 2006 through 2008. Unfortunately, the coding of countries changed across the waves and so our original strategy could not be implemented.

As an alternative approach to getting some insight into the rate of welfare use by refugees, we decided to look at immigrants from North and West Africa as a group. We should stress that this is a very imprecise approach to this issue as many refugees come from elsewhere in Africa and from elsewhere in the world. In Table 7, we show the results from probit regressions where the dependent variables are: all benefits (column 1), unemployment and disability only (column 2) and family related benefits (column 3). The controls are the same as those used in the earlier probits and so the results are comparable with the earlier tables.

As can be seen in Table 7, immigrants from Africa (North and West) do appear to have higher rates of welfare receipt relative to natives, when all benefits are combined. However, this observation is explained by a higher rate of receipt of family related benefits and not through receipt of unemployment or disability benefits.

With the exception of North and West African immigrants and their relatively higher rates of receipt of family benefits, the only cases in which there seem to be significant differences between immigrants and natives is with respect to unemployment and disability payments. For immigrants from non-English-speaking countries and for immigrants from the NMS, they are less likely to have received payments. An obvious question that arises is whether or not this was related to eligibility differences or possibly different rates of take-up across groups with similar eligibility.

This is a difficult question to address with the data available to us but we have attempted to provide some insight in the following way. We have once again run probit regressions but this time we have restricted the sample to immigrants and natives who are unemployed and we only consider unemployment and disability payments as the dependent variables. The results are shown in Table 8.

A number of important results emerge. For unemployed immigrants as a group, they are less likely to receive benefits relative to unemployed natives. However, the differences are not significant when we look at the sub-groups English-speaking and non-English speaking and EU15 and NMS, both for the 2008 sample only. However, when we look at the combined samples from 2006 and 2008, we see much stronger evidence of lower rates of receipt among immigrants.

As a final element in our analysis of the EU-SILC data, we address the question of whether or not any of the immigrant groups are at a greater risk of poverty relative to comparable Irish people. The results so far would suggest that the only group around whom we might have concerns is immigrants from the NMS as these are the only group who appear to be experiencing lower rates of welfare receipt across the broad 
range of benefits. To the extent that welfare fulfils its role of keeping people out of poverty, we would be less concerned about other groups based on the results so far.

In Table 9, we present the result from a regression in which the dependent variable is equal to one if the individual lives in a household where equivalised income is less than 60 percent of the median income. The sample is based on the pooling of the years 2006 to 2008. As can be seen, a surprising result to emerge is that immigrants from the pre-accession EU are more likely to be at risk of poverty relative to natives. Neither NMS nor North and West African immigrants are at greater risk but immigrants from "other countries" are. As the "other" group is quite diverse and covers countries such as China, India and Brazil it is difficult to provide a theory as to why this result has emerged. However, it will certainly be important to explore this more fully.

Section 4: The recession and trends in welfare receipt

Between 2008 and 2010, Ireland has experienced a deep recession. Real gross domestic product fell by a cumulative 11 percent between 2008 and 2009; the rate of unemployment increased from 4.9 percent at the beginning of 2008 to 13.6 percent in mid-2010. According to Barrett and Kelly (2010), the impact of the downturn has been particularly severe for immigrants, with annual employment losses being as high as 20 percent in mid 2009 as compared to 7 percent for natives.

In the analysis above, we generally found lower rates of welfare receipt among immigrants relative to natives and this was consistent with the operation of the habitual residency condition. Given the dramatic turnaround in the economy and its impact on non-natives, it is interesting to see if the operation of the habitual residence condition can be seen in official data on the numbers receiving unemployment benefits and payments.

In Figure 1, we plot the annual change in the numbers of national and non-nationals on the Live Register (i.e. "signing on" for unemployment benefits and assistance) for each month from June 2007 and October 2010. For each month, we have calculated the change on the same month of the previous year. It should be noted that we are observing changes in the stocks of national and non-nationals and that these stocks are made up of inflows and outflows. As can be seen, the rate of increase in the numbers of non-nationals on the Live Register exceeded that of nationals up to early 2009 and was also rising at a faster pace. This is consistent with the picture presented in Barrett and Kelly (2010) of significantly larger job losses among immigrants relative to natives in this period. The rate of increase in the numbers on the Live Register started to fall around April/May for both groups but the pace of the fall was steeper for nonnationals. By late 2009, the rate of increase for nationals exceeded that on nonnational and from mid-2010, the number of non-nationals was actually declining, in spite of continued increases for the nationals.

The trend depicted in Figure 1 could be consistent with a slower pace of job losses among non-nationals from mid-2010 onwards, relative to natives. However, the trend in the picture is also consistent with the following process. Immigrants who entered the Live Register may initially have been in receipt of unemployment benefits, having made the required number of social insurance contributions. However, when these 
benefits were exhausted after one year, they would have had to apply for the meanstested unemployment assistance payment. Their application would have been assessed and subjected to the five criteria mentioned above. A strict application of the criteria may have led to exits from the Live Register based on refused applications as opposed to more favourable labour market outcomes. We cannot test for this but merely outline it here as a possible explanation of what we observe in Figure 1.

\section{Section 5: Conclusion}

In the Introduction, we noted that Ireland had incorporated into its system of social welfare payments an explicit condition which was aimed at limiting the exposure of the welfare system to large-scale immigration. By initially imposing the habitual residency condition in 2004 and then replacing it with the five criteria listed in Section 2, the state was aiming to ensure that it could contain possible demands on the welfare system.

The results of our analysis would suggest that Ireland's approach to this issue has been successful. The analysis generally shows that in the years preceding the recession, immigrants were less likely to be in receipt of welfare payments, whether we look at adjusted or unadjusted data. The recession, and the consequent job losses among immigrants, gave rise to a possible surge in the numbers of immigrants receiving welfare benefits. While this seemed to happen at the outset of the recession, the more recent trends in the numbers on the Live Register would suggest that the numbers of non-nationals stabilised, even as the number of nationals on the Live Register continued to rise.

While the approach can be deemed as "successful" in terms of limiting the number of immigrants drawing benefits, there remains a question mark over the impact of the policy on poverty levels among immigrants. Our analysis of relative rates of poverty between immigrants and natives was based on data from 2008 and so we were not able to establish the impact of the recession. Given the evidence in Barrett and Kelly (2010) on the severity of the recession on immigrant employment, it is possible that the approach to immigrants in the welfare system is resulting in hardship and so a note of caution is needed. 


\section{References}

Barrett, A., Bergin, A. and Duffy, D. (2006), "The Labour Market Characteristics and Labour Market Impacts of Immigrants in Ireland”, Economic and Social Review Vol. 37 No. 1 pp. 1-26

Barrett A. and Duffy, D. (2008), “Are Ireland's Immigrants Integrating into Its Labour Market”, International Migration Review, Vol. 42 No. 3 pp 597-619

Barrett, A. and Kelly, E. (2010), “The Impact of Ireland's Recession on the Labour Market Outcomes of Its Immigrants”, IZA Discussion Paper no. 5218

Barrett, A. and Y. McCarthy (2007), "Immigrants in a Booming Economy: Analysing their Earnings and Welfare Dependence", Labour: Review of Labour Economics and Industrial Relations Vol. 21 No. 4-5 pp789-808

Barrett, A. and Y. McCarthy (2008), “Immigrants and Welfare Programmes: Exploring the Interactions between Immigrant Characteristics, Immigrant Welfare Dependence and Welfare Policy”, (2008), with Yvonne McCarthy, Oxford Review of Economic Policy Vol. 24 No. 3.

Borjas, George J. (1999), “Immigration and Welfare Magnets”, Journal of Labour Economics Vol. 17 No. 4 Part 1 pp. 607-637

Central Statistics Office (2009), EU Survey on Income and Living Conditions (EUSILC) 2008, Dublin: Stationery Office

Dustmann, C., Frattini, T. and Halls, C. (2010), “Assessing the Fiscal Costs and Benefits of A8 Migration to the UK”, Fiscal Studies, Vol. 31 No. 1 pp. 1-41

Hansen, Jörgen and Magnus Lofstrom (2009), “The Dynamics of Immigrant Welfare and Labor Market Behaviour”, Journal of Population Economics Vol. 22 pp. 941-970

Riphahn, R. T. (2004), 'Immigration Participation in Social Assistance Programs', Applied Economics Quarterly, Vol. 50 No. 4. 
Table 1: Proportions of Natives and Immigrants in Receipt of Social Welfare Payments, EU-SILC 2008

Social transfers*

Native

Immigrant

Immigrant (English

speaking)

Immigrant (non English

speaking)

EU 15

EU12

*Social transfers include UB \& DISAB, Family benefits

62.1

53.6

66.1

63.3

69.5

60.4

109
Unemployment benefits(incl disab)

Native

Immigrant

Immigrant (English

speaking)

Immigrant (non English

speaking)

EU 15

EU12

Family/children benefits

Native

Immigrant

Immigrant (English

speaking)

Immigrant (non English

speaking)

EU 15

EU12
27.5

16.7

29.3

13.1

50.1
54.5

.161

52.4

.679

55.5

.154 vs Natives

Pearson Chi-

Square Sig

.000

.725

.000

.102

.003

vs Natives

Pearson Chi-

Square Sig

49.1

.831

.809 
Table 2: Average ages, years worked and number of children, immigrant and natives, EU-SILC 2008

\begin{tabular}{lccc}
\hline & Age & $\begin{array}{c}\text { Years of } \\
\text { work }\end{array}$ & $\begin{array}{c}\text { Number of } \\
\text { children }\end{array}$ \\
Native & 43.6 & 21.5 & 2.0 \\
Immigrant & 37.4 & 15.8 & 1.8 \\
Immigrant (English & 46.5 & 23.6 & 1.9 \\
$\begin{array}{l}\text { speaking) } \\
\text { Immigrant (non English }\end{array}$ & 33.3 & 12.0 & 1.7 \\
speaking) & & & \\
EU 15 & 43.8 & 22.2 & 1.7 \\
EU12 & 29.8 & 9.3 & 1.6 \\
\hline
\end{tabular}

Table 3: Educational attainment, immigrants and natives, EU-SILC 2008

$\begin{array}{cccccc}\text { Native } & \text { Immigran } & \text { Immigrant } & \text { Immigrant } & \text { EU } & \text { EU } \\ & \mathrm{t} & \text { English } & \text { non English } & 15 & 12 \\ & & \text { speaking } & \text { speaking } & & \end{array}$

\begin{tabular}{lcccccc} 
No Quals & 20.4 & 15.5 & 14.6 & 15.9 & 11.2 & 22.6 \\
$\begin{array}{l}\text { Mid } \\
\text { secondary }\end{array}$ & 19.6 & 11.4 & 32.9 & 1.6 & 22.4 & 2.4 \\
$\begin{array}{l}\text { All } \\
\text { secondary }\end{array}$ & 33.8 & 28.0 & 17.1 & 33.0 & 20.7 & 46.4 \\
Low Tertiary & 19.1 & 33.7 & 28.0 & 36.3 & 31.9 & 22.6 \\
$\begin{array}{l}\text { High } \\
\text { Tertiary }\end{array}$ & 7.1 & 11.4 & 7.3 & 13.2 & 13.8 & 6.0 \\
Total & 100.0 & 100.0 & 100.0 & 100.0 & 100 & 100 \\
\hline
\end{tabular}


Table 4: Probit regressions, marginal effects, dependent variable: receipt of any benefit, EU-SILC 2008

\begin{tabular}{lccc}
\hline VARIABLES & Model 1 & Model 2 & Model 3 \\
immigrant & -0.0374 & & \\
& $(0.0333)$ & & \\
immig_eng & & 0.00124 & \\
& & $(0.0557)$ & \\
immig_non_eng & -0.0571 & \\
eu15 & $(0.0409)$ & \\
& & & -0.0231 \\
eu12 & & $(0.048)$ \\
& & & $-0.187^{* * *}$ \\
& & & $(0.0586)$ \\
\hline
\end{tabular}

Standard errors in parentheses

${ }^{* * *} \mathrm{p}<0.01,{ }^{* *} \mathrm{p}<0.05,{ }^{*} \mathrm{p}<0.1$

Table 5: Probit regressions, marginal effects, dependent variable: receipt of unemployment or disability payments, EU-SILC 2008

\begin{tabular}{|c|c|c|c|}
\hline VARIABLES & Model 1 & Model 2 & Model 3 \\
\hline immigrant & $\begin{array}{c}-0.0724 * * * \\
(0.0268)\end{array}$ & & \\
\hline immig_eng & & $\begin{array}{c}0.0153 \\
(0.0504)\end{array}$ & \\
\hline immig_non_eng & & $\begin{array}{c}-0.122^{* * *} \\
(0.0295)\end{array}$ & \\
\hline eu15 & & & $\begin{array}{l}-0.0397 \\
(0.0415)\end{array}$ \\
\hline eu12 & & & $\begin{array}{c}-0.115 * * * \\
(0.0399)\end{array}$ \\
\hline
\end{tabular}

Standard errors in parentheses

*** $\mathrm{p}<0.01,{ }^{* *} \mathrm{p}<0.05,{ }^{*} \mathrm{p}<0.1$ 
Table 6: Probit regressions, marginal effects, dependent variable: receipt of family related benefits, EU-SILC 2008

\begin{tabular}{|c|c|c|c|}
\hline VARIABLES & Model 1 & Model 2 & Model 3 \\
\hline immigrant & $\begin{array}{l}-0.00773 \\
(0.0114)\end{array}$ & & \\
\hline immig_eng & & $\begin{array}{c}0.0122 \\
(0.00917)\end{array}$ & \\
\hline immig_non_eng & & $\begin{array}{l}-0.0304 \\
(0.0232)\end{array}$ & \\
\hline eu15 & & & $\begin{array}{l}0.00374 \\
(0.0115)\end{array}$ \\
\hline eu12 & & & $\begin{array}{l}-0.0478 \\
(0.0387)\end{array}$ \\
\hline \multicolumn{4}{|c|}{$\begin{array}{l}\text { Standard errors in parentheses } \\
* * * \mathrm{p}<0.01,{ }^{* *} \mathrm{p}<0.05,{ }^{*} \mathrm{p}<0.1\end{array}$} \\
\hline \multicolumn{4}{|c|}{ Table 7: Probit Results for African Immigrants, EU-SILC 2008} \\
\hline Variable UB & $\begin{array}{l}\text { DISAB \& } \\
\text { AMB }\end{array}$ & UB \& DISAB & FAMB \\
\hline Imm & $221 * * *$ & 0.117 & $0.303^{* * *}$ \\
\hline Africa & $.0568)$ & $(0.0738)$ & $(0.0673)$ \\
\hline
\end{tabular}

Table 8: Probit regressions, marginal effects, dependent variable: receipt of unemployment or disability payments - unemployed only, EU-SILC 2008

\begin{tabular}{|c|c|c|c|c|}
\hline VARIABLES & Model 1 & Model 2 & Model 3 & $\begin{array}{c}\text { Model } 4 \text { (pooled } \\
\text { sample 2006- } \\
\text { 2008) }\end{array}$ \\
\hline immigrant & $\begin{array}{c}-0.248 * \\
(0.132)\end{array}$ & & & \\
\hline immig_eng & & $\begin{array}{l}-0.329 \\
(0.262)\end{array}$ & & \\
\hline immig_non_eng & & $\begin{array}{c}-0.224 \\
(0.149)\end{array}$ & & \\
\hline eu15 & & & $\begin{array}{l}-0.341 \\
(0.215)\end{array}$ & $\begin{array}{c}-0.138 \\
(0.0858)\end{array}$ \\
\hline eu12 & & & $\begin{array}{c}-0.000593 \\
(0.188)\end{array}$ & $\begin{array}{c}-0.323^{* *} \\
(0.161)\end{array}$ \\
\hline Africa & & & & $\begin{array}{c}-0.386^{*} \\
(0.202)\end{array}$ \\
\hline Other & & & & $\begin{array}{c}-0.209 * \\
(0.122)\end{array}$ \\
\hline
\end{tabular}

Standard errors in parentheses

${ }^{* * *} \mathrm{p}<0.01,{ }^{* *} \mathrm{p}<0.05,{ }^{*} \mathrm{p}<0.1$ 
Table 9: Probit regression, marginal effects, risk of poverty, pooled sample EU-SILC 2006 to EU-SILC 2008

\begin{tabular}{|c|c|}
\hline VARIABLES & Marginal effect \\
\hline eu15 & $\begin{array}{c}0.0808 * * * \\
(0.0179)\end{array}$ \\
\hline eu12 & $\begin{array}{l}-0.0254 \\
(0.0161)\end{array}$ \\
\hline africa & $\begin{array}{c}0.051 \\
(0.0569)\end{array}$ \\
\hline other & $\begin{array}{c}0.0772 * * * \\
(0.0296)\end{array}$ \\
\hline $\begin{array}{l}\text { number of children } \\
\text { aged less than } 18\end{array}$ & $\begin{array}{c}0.0267 * * * \\
(0.0019)\end{array}$ \\
\hline single_female & $\begin{array}{c}-0.0434 * * * \\
(0.00591)\end{array}$ \\
\hline married_male & $\begin{array}{c}-0.0667 * * * \\
(0.00527)\end{array}$ \\
\hline married_female & $\begin{array}{c}-0.0719 * * * \\
(0.00481)\end{array}$ \\
\hline Years_Work & $\begin{array}{c}-0.000997 * * * \\
(0.000371)\end{array}$ \\
\hline Years_wrk2 & $\begin{array}{c}3.76 \mathrm{E}-06 \\
(5.23 \mathrm{E}-06)\end{array}$ \\
\hline Secondar & $\begin{array}{l}-0.157 * * * \\
(0.00501)\end{array}$ \\
\hline Tertiary & $\begin{array}{l}-0.122 * * * \\
(0.00291)\end{array}$ \\
\hline Observations & 19341 \\
\hline LR chi2 & 1681 \\
\hline Prob > chi2 & 0 \\
\hline Pseudo R2 & 0.11 \\
\hline
\end{tabular}

Standard errors in parentheses

*** $\mathrm{p}<0.01,{ }^{* *} \mathrm{p}<0.05,{ }^{*} \mathrm{p}<0.1$ 
Figure 1: Annual rate of increase in numbers on the Live Register, June 2007 to October 2010

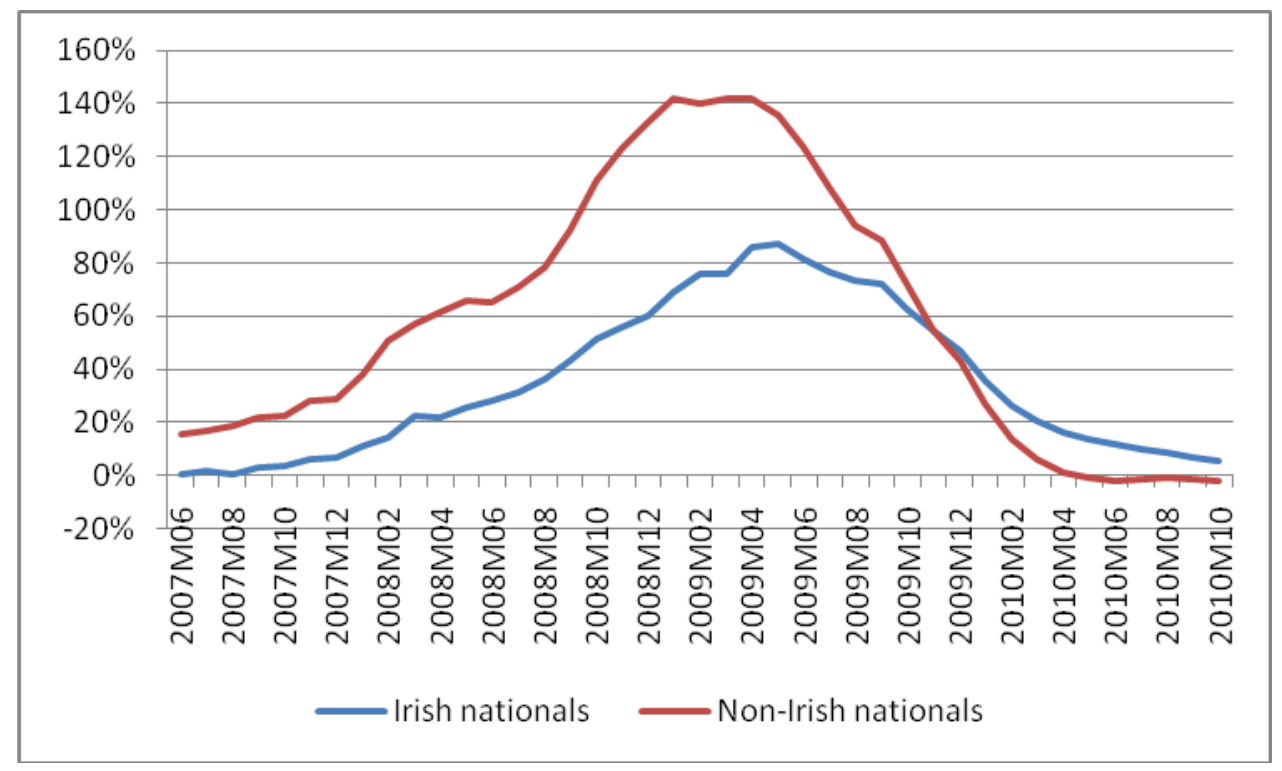

